\title{
The Impact of Using Mindfulness-Based Stress Reduction (MBSR)intervention for Reducing Teacher Burnout and Enhancing Self-efficacy of teachers of Autism Syndrome Disorder (ASD)
}

\author{
Dr. Moudi Abdullah Amer Alajmi \\ Autistic Behavior School, Ministry of Education, Kuwait
}

\begin{abstract}
The current study aimed to explore the effectiveness of using Mindfulness-Based Stress Reduction (MBSR) intervention on reducing teacher burnout of teachers of Autism Syndrome Disorder (ASD).It is also aimed to investigate the impact of decreased teachers' burnout on enhancing the self-efficacy of those teachers. To achieve such goal, Mindfulness-Based Stress Reduction (MBSR) intervention and Oldenburg teacher burnout inventory, and Self-efficacy Scale. The sample of the study consists of 32 teachers who teach autistic children in the Autistic Behavior School (ABS) in Jahraa district, in the State of Kuwait. They were divided into two groups; the experimental group including 15 ASD teachers and the control group that includes 17 teachers. Both quantitative and qualitative designs were used; the quasi-experimental research design has been adopted in this study to assess the improvement achieved by the experimental group compared with the control group as a result of using the MBSR intervention program. Also, semi-structured interviews have been held with certain teachers with a high level of burnout. Results of the study revealed statistically significant differences in the mean scores of experimental and control groups in favor of the experimental group. MBSR intervention was effective in alleviating teachers' burnout and enhancing their self-efficacy. Based on the study results, it is recommended that mindfulness strategies should be used to alleviate anxiety, depression, stress, and even burnout teachers experience due to their job especially those teaching children with disabilities and autism.
\end{abstract}

Keywords: Mindfulness-Based Stress Reduction (MBSR); teacher burnout;self-efficacy;Autism

Article Received: 10 August 2020, Revised: 25 October 2020, Accepted: 18 November 2020

\section{Introduction}

In recent decades, the development of a research study has highlighted burnout as a worrying concern for educational policymakers (Droogenbroeck, et al., 2014; Jacobson, 2016, Ford, et al.,2019, Ansley, et al.,2021) and educational managers, mainly because of the expenses of mental health and wellness treatment for instructors, the increase in healthcare costs, and also, ultimately, the increase in healthcare costs (Craig,2017). Teachers usually face day-to-day challenging needs and work challenges that require a high level of emotional involvement in their work, regardless of the level of education, the students' type, and the learning they demonstrate (Extremera, et al.,2010; Kyriacou,2001).

When these demands exceed the business and/or personal resources that educators have, as well as the situation, gradually becomes persistent, it promotes the appearance of conditions as well as symptoms associated with stress and anxiety, depression, tension, and the supposed syndrome of exhaustion (Martínez-Monteagudo, et al.,2019).Then there are attitudes and behaviors of indifference called indolence, sometimes abusive towards the client; and finally, guilt caused by attitudes or indolent behavior (Figueiredo-Ferraz et al.,2016; Gil-Monte,2007; Rabasa et al.,2016).

Burnout describes the endpoint of coping with chronic stress at work ineffectively and emotional exhaustion is understood to be a key component of burnout (Maslach et al.,2001). Teachers of children with autism syndrome disorder (ASD) face numerous difficulties in teaching those childrenbecause autistic children suffer deficiencies in attention, communication, and executive functions (Boonen, et al.,2014). ASD is characterized by persistent impairments in reciprocal social interaction and communication across multiple contexts, as well as the presence of restricted, repetitive, and stereotypical behaviors and interests (American Psychiatric Association, 2013).Current evidence suggests that children with ASD often have high levels of co-occurring behavioral problems (Bauminger, Solomon, \& Rogers,2010; Gray, Keating, Taffe, \& Brereton,2012; Hartley, Sikora, \& McCoy,2008;

Kanne\&Mazurek,2011; Mazurek\&Kanne,2010). Problems frequently present in children with ASD include both internalized problems consisting of depressed/anxious affect, 
somatic complaints, besides withdrawal, and externalized problems that consist of aggression, hyperactivity, and property destruction (Boonen, et al.2014).Special education teachers have been notified to be particularly vulnerable to burn-out (Emery \& Vandenberg, 2010; Lee et al. 2011).

Mindfulness literature is constantly expanding, requiring updated reviews regularly. Mindfulness, defined as moment-to-moment awareness, is a skill that can be learned through practice and is believed to promote well-being (Brown, \& Ryan, 2003).Mindfulness has received interest from clinicians and researchers because it appears to improve the acceptance of symptoms that are difficult or impossible to change, to establish cognitive metareflective capacity that enhances the degree of freedom of patients, and to help patients change their focus by emphasizing current experience (Fjorback, et al., 2011). These potential mechanisms are not part and parcel of established treatment programs, and therefore, mindfulness promises to offer something new to patients (Wallace \& Shapiro, 2006; Kohls, et al., 2009).

Mindfulness is defined as "purposefullypaying attention and being present in the moment"(KabatZinn2003, p. 145).Mindfulness-based intervention is an effective way to reduce stress and improve the well-being of a variety of populations (Kallapiran et al. 2015; Khoury et al. 2013; Piet et al. 2012) including parents and caregivers (Birnie et al. 2010; Bögels et al. 2008, 2014; Epstein-Lubow et al. 2011; Van der Oord et al. 2012; Whitebird et al. 2012;Bazzano, et al. 2013;Ridderinkhof, et al. 2018, Singh, et al. 2014), teachers of autistic children (Harmony \& Woodard, 2020;Kabat-Zinn, 2003), and autistic children themselves (Cachia et al.2016; Spain et al. 2015; Lunsky, et al. 2017)

In a related context, self-efficiency refers to the judgments of individuals on their capacity to meet specific environmental requirements (Bandura, 1997). According to social cognitive theory, when people feel they are capable of meeting challenges, they make more effort, are more willing to persist and persevere, and are better equipped to cope with them (Bandura, 1997). In the educational context, teachers' self-efficiency is a belief in his/her ability to deliver content effectively, manage the classroom environment, and engage students successfully. Teacher trust influences student outcomes through teachers' behavior and student learning (Klassen, Tze, Betts, \& Gordon, 2011). Teacher self-efficiency is also related to psychosocial factors such as job satisfaction, stress, and job burnout (Betoret, 2006; Klassen\& Chiu, 2010; Schwarzer\&Hallum, 2008). In the case of special educators, self-efficacy may be particularly salient because they are prone to higher stress, burnout, and attrition compared to general educators (Awa, Plaumann, \& Walter, 2010).

Given the state of current evidence, the principal aim of the present study was to examine the effectiveness of using Mindfulness-Based Stress Reduction (MBSR) intervention on reducing teacher burnout (primary outcome) and enhancing selfefficacy of teachers of Autism Syndrome Disorder (ASD) (secondary outcomes). Based on the findings ofHarmony \& Woodard, (2020) and Kabat-Zinn, (2003), using mindfulness strategies helped to a large extent in alleviating autistic children teachers.A secondary aim was to establish whether this finding replicates andwhether the decreased levels of teacher burnout help enhancing teachers' self-efficacy of autism teachers and therefore would influence these possible process of change variables over time.

\subsection{Teacher Burnout\&Autism Teachers}

Teachers often experience burnout and challenges in their active careers (Zarafshan, et al. 2013).Job burnout is considered to be a consequence of longterm stressful working conditions among human service workers, especially teachers, as teaching is measured by one of the stressful professions (Jennett, et al. 2003).Teachers usually face day-to-day challenging needs and work challenges that require a high level of emotional involvement in their work, regardless of the level of education and learning they demonstrate (Extremera, et al., 2010; Kyriacou, 2001).

Teaching is considered a very difficult occupation and has historically been one of the highest possible stress-related jobs (Johnson et al., 2005).A multitude of studies have revealed high levels of stress and burnout experienced by teachers (see e.g., Cunningham, 1983; Kyriacou, 1987, 2001; Kyriacou\& Sutcliffe, 1977; Salo, 1995; Seidman\&Zager, 1991).According to Maslach and Jackson (1981), burnout is defined as "a syndrome of emotional exhaustion and cynicism that occurs among individuals who do some kind of 'people's work"' (p. 99). Burnout disorder was first identified by Freudenberger (1974) and further consolidated by Maslach's (1976) pioneering work.

According to Maslach and Jackson (1986), the burnout disorder syndrome consists of three specific signs or symptoms: (1) psychological fatigue, i.e. the professional feels unable to offer even more of himself, feeling worn out when he tries to meet the demands that overwhelm him, creating discouragement and aggravation;(2) 
Depersonalization, which causes professionals to demonstrate insensitivity to clients i.e. when issues that disrupt his/her mentoring work proceed with time, the instructor will examine these individuals as his/her adversaries and, as a result, will develop defensive approaches to protect himself/herself, which will put right in distancing, cold interactions.Besides, (3) reduced individual achievement, i.e., the non-achievement of job objectives converts right into solid feelings of inexperience and failure; the professionals perceive that the labor demands exceed their capacities, hence resulting in negative self-evaluation.

Burnout has been identified as a major contributor to attrition in previous research (Wong et al., 2017). Even in the United States of America, teacher burnout has led to a sustained reduction in the number of special education teachers (Emery \& Vandenberg, 2010; Fore et al., 2002; Leko and Smith, 2010).Teachers often experience burnout and challenges in their active careers. Various studies have shown that those directly involved in teaching children with special needs are more likely to be burnt out (Zarafshan et al. 2013). Recent studies have shown that the level of job burnout is related to general physical and mental health (Huberman, 1993). Teacher's performance in their social life, personal relationship, and job satisfaction aresignificant factors in their attitude toward jobs (Hastings, et al. 2004; Weiss, 2002).There are several students, teacher, and school-related variables related to the onset of burnout of special education teachers. These variables are closely aligned with the realities of the day-to-day work experience of special education teachers; therefore, it is crucial to provide them with the means to reduce burnout before they produce negative outcomes (Brunsting et al., 2014).

The schooling of children with ASD may take place in different contexts: in regular classes, in specialized classes in a regular school, or a specialized institution. The manifestations of ASD vary in intensity and can therefore be more or less difficult for teachers to manage. The most common difficulties experienced by teachers in regular schools and specialized schools concerning children with ASD are their limited attention and concentration and lack of integration with other children (Rattaz et al. 2013).In fact, because of the disorder, children with ASD usually withdraw from social interactions (e.g., reduced sharing of interests, emotions or affect, or lack of interest in peers, sometimes giving the impression that others do not exist for them. This is unsettling with an adverse impact on student-teacher relationships as well as teachers' emotions (Nistor\& Chilin,2013). Besides, these challenging behaviors represent a source of stress for teachers: aggressive behaviors are the most difficult for teachers to manage and are associated with high levels of stress. Therefore, teachers of students with special needs in general and autistic students in particular need to adopt calming techniques to alleviate the severe burnout they suffer, otherwise high levels of attrition occur.

\subsection{Mindfulness-based stress reduction (MBSR)}

Mindfulness-based stress reduction (MBSR) is a program that aims to reduce stress by developing mindfulness, meaning a non-judgmental, accepting moment-by-moment awareness (Schell, et al. 2019).MBSR appears to be an effective intervention to reduce the co-morbid symptoms of depression, anxiety, and distress in high functioning adults with ASD. They are also able to actively acquire techniques that can help them gain more control and have a positive impact on their wellbeing.Mindfulness-based programs may support children with ASD for some reasons. First, the underlying neurocognitive deficits may improve. Central coherence could be improved by mindfulness because children practice shifting between widening and narrowing their attention. Instead of paying excessive attention to details that automatically attract attention in ASD, participants train to view both internal and external experiences as passing events in a wider area of awareness (KabatZinn,1994; Segal et al. 2012).

Mindfulness-based programs are based on Buddhist traditions;Mindfulness meditation and mental healthcare adaptation based on Western Psychology. Participants train to pay attention to the present moment, on purpose, and with a non-judgmental, open-minded, and curious attitude (KabatZinn,1994). They train increased attention and awareness of experiences such as body sensations, feelings, thoughts, and senses. Also, mindfulness practices are taught to cultivate an acceptance and compassionate attitude towards experience (Segal et al. 2012).

Mindfulness-based intervention greatly helps improve central coherence and executive functioning. Besides, this intervention may lead to reducing social communication and interaction problems. Participants/teachers produce awareness of the current moment, including the communications and interactions with other persons.Being able to pay more attention to social interactions could help participants to be more able to attend to others instead of being distracted by, for example, ruminative thoughts or sounds in the environment (Ridderinkhof, et al. 2018). Moreover, mindfulness 
can lead to a better understanding of emotional feelings by practicing awareness of one's feelings. It may thus enhance the understanding of the feelings of others as well. Mindfulness can also lead to increased awareness of the impact on others of one's behaviors (Block-Lerner et al. 2007; Sequeira\& Ahmed, 2012). Therefore, mind theory, empathy, and social interaction could be enhanced by programs based on mindfulness.

Thirdly, mindfulness-based programs can improve the coping skills of teachers of children with ASD by associating their experiences, thoughts, and feelings with less judgmental, more curious, accepting, and compassionate. For instance, teacherspractice being aware of the connection between body sensations, emotions, and thoughts instead of being caught up in thoughts, trying to understand their feelings. They learn to allow them, to see them as events that pass by, and to bring their attention back to the present moment. This training could thus reduce their increased stress, emotional, and behavioral levels.According to Chiesa and Serretti (2009), Gotink et al. (2015), and Hofmann et al. (2010), mindfulness training could reduce increased levels of stress, emotional and behavioral problems. Indeed, in adults with different psychiatric or medical conditions, mindfulness-based programs reduce stress in healthy adults and reduce stress, anxiety, and depressive symptoms. Furthermore, a mindfulnessbased program was found to reduce ADHD symptoms in children and adolescents (Van der Oord et al.2012; Van deWeijer-Bergsma et al. 2012; Zylowska et al. 2008).

\subsection{Teachers' self-efficacy}

Job burnout is categorized as a group of symptoms such as emotional exhaustion, depersonalization, and reduced self-efficacy (Maslach, et al. 1996; Maslach\& Jackson, 1981). According to Maslach et al. (1996), emotional exhaustion has been identified as the main definition of burnout, which is characterized by reduced energy levels and extreme fatigue. Depersonalization in teachers is also defined by negative emotions and attitudes towards both students and colleagues. Reduced self-efficacy is defined by the tendency of teachers to have negative self-assessment and a lack of personal achievement.

Teacher self-efficacy, rooted in social cognitive theory (Bandura, 1977), emphasizes that the actions of teachers and their self-confidence are often a stronger predictor of self-confidence than their immediate capabilities. Self-efficacy beliefs, or the ability to believe in one's ability to succeed in a situation, are described as influences on one's thinking, feeling, and behavior. Motivation, cognition, affect, and selection processes are influenced by perceived self-efficiency. Confidence, self-confidence, and self-assurance are the terms used to describe such perceptions. Self-efficiency influences achievement, commitment, interest, and goal-setting and, besides, leads to self-efficiency including an increased sense of effort and focus on tasks (Bandura, 1993).

Bandura (1997) elaborated on the construction and described four sources of influence on one's selfefficacy: (a) mastery of experiences requiring sustained, persistent effort; (b) vicarious experience; (c) social persuasion; and (d) emotional and physiological states. In the context of teaching, selfefficacy and its influence are seen as important factors in teacher performance and student learning. These four processes provide theoretical support for subsequent research and development on teacher selfefficacy scales (Guskey\&Passaro, 1994; Ruble et al., 2011; Tschannen-Moran,Woolfolk Hoy, \& Hoy, 1998)

Self-efficiency in teaching is a belief in one's ability to deliver content effectively, manage the classroom environment, and engage students successfully (Ruble, Usher, \& McGrew, 2011). Self-efficiency is also related to psychosocial factors such as job satisfaction, stress, and job burnout (Betoret, 2006; Klassen\& Chiu, 2010; Schwarzer\&Hallum, 2008).Teachers' belief in efficacy could potentially have an impact on the approach to all learning experiences and could therefore play a leading role in guiding behaviors in the design of the teaching environment and inactions within that environment (Fives \&Buehl, 2008; Pajares, 1996).

Self-efficiency research may be particularly relevant to special educators who are prone to higher stress, burn-out, and attrition compared to general educators (Awa, Plaumann, \&Walter, 2010).Recent research suggests that students with autism, in particular, may place more stress on teachers than other groups of students, such as those with emotional or behavioral problems, attention deficit hyperactivity disorder (ADHD), or cognitive disabilities (Coman et al., 2012; Jennett, Harris, \&Mesibov, 2003; Kokkinos \&Davazoglou, 2009). This lowers a teacher's sense of efficacy for working effectively with suchstudents (Ruble, Usher, \& McGrew, 2011). Teachers of students with autism may experience increased criticism of the quality and results of the programs and increased interactions with parents, teachers, and other providers of treatment. Besides, research suggests a disproportionately higher rate of conflict regarding the education of children with autism 
compared to other categories of disability (Zirkel, 2011).

\section{Methods}

Participants were recruited from one of the autism specialized schools; The Autistic Behavior School, in the state of Kuwait. Teachers were offered a short online presentation on the background to Mindfulness, some evidence for its use in stress management, and short meditation practices similar to those on the program. The sample of the study consists of 32 teachers who teach autistic children in the Autistic Behavior School (ABS) in Jahraa district, in the State of Kuwait. They were divided into two groups; the experimental group including 15 ASD teachers and the control group that includes 17 teachers. Thirteen qualified teachers and two teaching assistants from six local primary schools were recruited. Detailed demographic information was not collected.Of the fifteen participants, seven were males, with ages ranging from the late 30 s to late 50 s. Participants were self-selected and all identified themselves as experiencing stress. None of the participants had any current medical or mental health difficulties that justified exclusion from the course, and none had any previous experience of meditation. Data from two participants are omitted, as these persons did not provide post-course data.

\section{Measures}

To measure teacher burnout and teacher self-efficacy, course participants completed the Oldenburg Burnout Inventory (OLBI) (Demerouti et al., 2010) and teacher self-efficacy (Schwarzer, Schmitz, \&Daytner, 1999) before and after taking the MBSR course.

Burnout: Teacher burnout was assessed using Oldenburg Burnout Inventory (OLBI) (Demerouti et al., 2010), the OLBI was used to assess burnout that includes 16 items, the inventory was initially made in the German language (Demerouti\&Nachreiner, 1998, 1999). It is a self-report five-point rating scale $(1=$ "Strongly disagree"; to 5 = "Strongly agree") with eight questions within each of the two dimensions, disengagement, and exhaustion (Demerouti et al., 2001). The disengagement factor refers to distancing from work in terms of both object and content, and to the development of cynical and negative attitudes and behaviors concerning one's job (Bakker et al., 2004).
Exhaustion refers to feelings of physical fatigue, the need to rest, and feelings of overtaxing and emptiness about work (Demerouti\& Bakker, 2008). In this study, the test internal consistency reliability, Cronbach's alpha coefficient was $(\mathrm{a}=.86)$.

Teacher Self-efficacy:In 1995, a scale was developed to measure teacher self-efficacy (Schwarzer, Schmitz, \&Daytner, 1999). The first step was to identify different job skills within the teaching profession. Four major areas were: (a) job accomplishment, (b) skill development on the job, (c) social interaction with students, parents, and colleagues, and (d) coping with job stress. For each of these four domains, teachers may hold different self-efficacy expectations. The total score of the scale has good overall reliability $(\mathrm{a}=.83)$.

Intervention: As the author received training in MBSR, participants undertook an 8-week course taught by the author of the current research, so she is well experienced in MBSR. Information was provided to participants about the course and the importance of taking responsibility throughout the course for their well-being. In between weekly sessions, the course teacher was available for support through WhatsApp and e-mail, and any participant who unexpectedly failed to attend was contacted. The course was delivered as 2hours weekly sessions immediately following the school day, including a 5 hours 'silent day' conducted between weeks 5 and 6 on Saturdays. In the Autistic Behavior School, examples and discussions were drawn from the working lives of the participants. The syllabus of the course closely followed those defined by Kabat-Zinn (1990).

\section{Results}

Pre- to post-training changes in OLBI and TES scores were analyzedusing the Wilcoxon Signed Ranks Test (Wilcoxon, 1945). The improvements on teacher burnout subscales weresignificant $(\mathrm{p}=.01)$ for bothdisengagementand exhaustion, and on the teacher, self-efficacy was $(\mathrm{p}=.05)$. The Wilcoxon Signed Ranks Test was also used toassess whether there was a significant difference betweenpre-and post-scores on both OLBI and TES for both the experimental and control group. 
Table 1 presents the participants' pre-training teacher burnout scores. It shows that most teachers were suffering fromsignificant teacher burnout in the pretesting of both experimental and control groups.

\begin{tabular}{|c|c|c|c|c|c|c|c|c|c|c|}
\hline \multicolumn{2}{|l|}{ Time } & \multicolumn{2}{|c|}{$\begin{array}{l}\text { Before the } \\
\text { intervention }\end{array}$} & \multicolumn{2}{|c|}{$\begin{array}{c}\text { After the } \\
\text { intervention }\end{array}$} & \multirow[t]{2}{*}{$\begin{array}{l}\text { Mean } \\
\text { Rank }\end{array}$} & \multirow[t]{2}{*}{$\begin{array}{l}\text { Sum } \\
\text { of } \\
\text { Ranks }\end{array}$} & \multirow[t]{2}{*}{$\mathbf{Z}$} & \multicolumn{2}{|c|}{$\begin{array}{l}\text { Difference between } \\
\text { the scores before and } \\
\text { after the intervention }\end{array}$} \\
\hline Group & N. & Mean & SD & Mean & SD & & & & Mean & SD \\
\hline Control & 17 & 41.80 & 3.96 & 40.70 & 3.72 & 24.00 & 408.00 & 4.840 & -1.10 & 2.35 \\
\hline Intervention & 15 & 40.94 & 3.74 & 26.60 & 2.82 & 8.00 & 120.00 & $<0.01$ & -14.36 & 1.20 \\
\hline
\end{tabular}

The pretesting scores of both the control group and experimental group were higher than that of the post-testing of the experimental group. The heightened degree of burnout witnessed by the two groups before the implementation of the MBSR intervention has been drastically changed as manifested in the post-testing scores. Almost all of the participants scored above the clinical cut-off on both subscales; disengagement and exhaustion, with several of these falling within the severe or extremely severe ranges. After the implementation of the MBSR training, participants' scores on the burnout scale were lower than the clinical cut-off scores in both subscales denoting the effectiveness of MBSR training in stress and burnout reduction.

Table 2presents the participants' pre-and post-training teacher self-efficacy scores. It shows that most teachers scored low on the teacher self-efficacy scalein the pretesting session for both experimental and control groups.

\begin{tabular}{|c|c|c|c|c|c|c|c|c|c|c|}
\hline \multicolumn{2}{|l|}{ Time } & \multicolumn{2}{|c|}{$\begin{array}{l}\text { Before the } \\
\text { intervention }\end{array}$} & \multicolumn{2}{|c|}{$\begin{array}{c}\text { After the } \\
\text { intervention }\end{array}$} & \multirow[t]{2}{*}{$\begin{array}{l}\text { Mean } \\
\text { Rank }\end{array}$} & \multirow[t]{2}{*}{$\begin{array}{l}\text { Sum of } \\
\text { Ranks }\end{array}$} & \multirow[t]{2}{*}{$\mathbf{Z}$} & \multicolumn{2}{|c|}{$\begin{array}{l}\text { Difference between the } \\
\text { scores before and after } \\
\text { the intervention }\end{array}$} \\
\hline Group & N. & Mean & SD & Mean & SD & & & & Mean & SD \\
\hline Control & 17 & 19.20 & 3.36 & 19.00 & 3.10 & .00 & .00 & 4.846 & .20 & .46 \\
\hline Intervention & 15 & 18.60 & 3.12 & 30.12 & 18.60 & 8.00 & 120.00 & $\begin{array}{c}< \\
0.01\end{array}$ & 11.52 & 3.20 \\
\hline
\end{tabular}

Teacher self-efficacy of both experimental and control groups seems to be equal, both of them are low compared with that achieved by the experimental group after the MBSR training. It may be attributed to the decreased level of teacher burnout reflected in an enhanced sense of ability and competence.

\section{Discussion}

This study focused on teacher burnout within a selfselected sample of autistic children school teachers. The results showed that most teachers were suffering from teacher stress and burnout. All scored above the medium scores in the OLBI, with two-thirds scored significant range on the two subscales. The stress teachers experienced due to the high levels of teachers' burnout of participants was associated with self-reported impairments of motivation, selfconfidence, and concentration in teaching tasks achievements. Due to the small sample size, it is not possibleto draw generalizable conclusions as to whether thesample itself was atypical, or whether teachers in autism schools are a distressed occupational group compared with their counterparts teaching ordinary students.

Most participants experienced reductions in stress and burnout levels as a result of participating in theMBSR course, as shown by changes in the OLBI scores.Post-intervention, almost all participants scored low on the OLBI scale. Twoparticipants reported morestress at follow-up, despite achieving 
their personal goals and feeling that the course had been helpful. This may beexplained by life events occurring during the course andcould have been independent of it. These findings broadly reflect others' findingsof the effectiveness of MBSR as a stress managementstrategy (Baer 2003; Brown and Ryan 2003).

Before the MBSR course, participants set main goals fortheir desired achievements through taking the course. Onaverage, participants reported that they had progressed $73 \%$ of the way to these goals in less than three months.Although small, these findings are sufficiently positive toencourage further study. If our findings prove to hold morewidely, MBSR may be an efficacious and potentially cost-effectiveintervention for occupationally stressed teachers. The current study did not adopt the qualitative methodology; however, participants made someimportant and revealing statements about the impact thecourse had on them. For example, participants commented," I declined the idea of leaving teaching profession", " I changed the way I think about teaching children with autism", and another noted that " there are some ways to get the positive out of the negative sides of the profession".

\section{Conclusions}

There are several limitations to the study. The small size of the sample leads to tentative conclusions. Besides, there was a theoretical danger that an underpowered study could not detect the actual effects of the intervention. The fact that statistically significant effects have been found indicates that a replication study with a larger sample would be worthwhile. Since the sample was self-selected, it is difficult to conclude whether or not the high levels of distress reported are typical for primary school teachers. The current study focused mainly on autism teachers, which further limits the study, as it is not possible to determine whether any observed change is directly due to the intervention itself or the nature of the study sample.

Another limitation is that the author used an independent variable as the main intervention tool. In addressing this issue, a larger study could investigate both MBSR in comparison to the second treatment of another stress-reduction intervention. This twotreatment arm trial design would allow comparisons to be made between evidence-based stress reduction interventions, exploring any additional benefits of mindfulness practice in reducing stress and burnout.

Bearing in mind that training is intended to bring both long-term and short-term benefits, a follow-up after at least several months would further strengthen the study and could have shown different effects to the findings reported here. Failure to record changes in the main problem measure over time-limited the usefulness of this measure and, as a consequence, the amount of data collected. Measures used; OLBI and TES may also be one of the constraints, other autismbased specialized measures may have been useful in assessing improvement after investing time and effort in training in mindfulness. Further studies should be carried out to reflect on the actual progress of longterm follow-up participants. This problem would be addressed through the study of long-term changes and the stability of those changes.

In summary, the findings of the study indicate that mindfulness training benefits will enhance personal well-being, reduction of mental health concerns, the achievement of personally related goals, and increased the ability to fulfill the teaching requirements in a modern primary school after mindfulness training.

\section{References:}

American Psychiatric Association (2013).Diagnostic and statistical manual of mental disorders (5th ed.). Washington, DC: APA.

Ansley, B. M., Houchins, D. E., Varjas, K., Roach, A., Patterson, D. \&Hendrick, R. (2021). The impact of an online stress intervention on burnout and teacher efficacy.Teaching and Teacher Education,98, February 2021, https://doi.org/10.1016/j.tate.2020.103251.

Awa, W. L.; Plaumann, M. \&Walter, U. (2010).Burnout prevention: A review of intervention programs. 78(2):18490.DOI: $10.1016 /$ j.pec.2009.04.008

Baer, R. (2003). Mindfulness Training as a Clinical Intervention: A Conceptual and Empirical Review. Clinical Psychology Science andPractice, 10(2):125 -143. Doi:10.1093/clips.bpg015

Bandura, A. (1977). Self-efficacy: Toward a unifying theory of behavioral change. Psychological Review, 84, 191-215.

Bandura, A. (1977). Self-efficacy: Toward a unifying theory of behavioral change. Psychological Review, 84, 191-215.

Bandura, A. (1993). Perceived self-efficacy in cognitive development and functioning. Educational Psychologist, 28, 177-192. 
Bandura, A. (1993). Perceived self-efficacy in cognitive development and functioning. Educational Psychologist, 28, 177-192.

Bauminger, N., Solomon, M., \& Rogers, S. J. (2010). Externalizing and internalizing behaviors in ASD. Autism Research, 3, 101-112.

Bazzano, A.; Wolfe, Ch., Zylowska, L., Wang, S.; Schuster, E., Barrett, Ch.; Lehrer, D. (2013). Mindfulness-Based Stress Reduction (MBSR) for Parents and Caregivers of Individuals with Developmental Disabilities: A Community-Based Approach. Journal of Child and Family Studies, 24,

298-308 (2015).https://doi.org/10.1007/s10826-013-98369.

Betoret F. D. (2006).Stressors, self-efficacy, coping resources, and burnout among secondary school teachers inSpain.Educational Psychology, 26:519-539.

Birnie, K., Garland, S. N., \& Carlson, L. E. (2010). Psychologicalbenefits for cancer patients and their partners participating inmindfulness-based stress reduction (MBSR). Psycho-Oncology,19(9), 1004-1009.

Block-Lerner, J., Adair, C., Plumb, J. C., Rhatigan,D. L.,\&Orsillo, S. M.(2007). The case for mindfulness-based approaches in the cultivationof empathy: Does nonjudgmental, present-moment awarenessincrease capacity for perspective-taking and empathic concern?Journal of Marital and Family Therapy, 33, 501-516.

Bögels, S. M., Hellemans, J., van Deursen, S., Römer, M., \& van derMeulen, R. (2014). Mindful parenting in mental health care:Effects on parental and child psychopathology, parental stress,parenting, co-parenting, and marital functioning. Mindfulness, 5(5), 536-551.

Bögels, S., Hoogstad, B., van Dun, L., de Schutter, S., \&Restifo, K.(2008). Mindfulness training for adolescents with externalizingdisorders and their parents.Behavioral and Cognitive Psychotherapy,36(02), 193-209.

Boonen, H., Maljaars, J., Lambrechts, G., Zink, I, Van Leeuwen, K. \&Noens, I. (2014). Behavior problems among school-aged children with autism spectrum disorder: Associations with children's communication difficulties and parenting behaviors. Research in Autism Spectrum Disorders, 8, 716-725, DOI: 10.1016/j.rasd.2014.03.008
Brown, K. W. \& Ryan, R. M. (2003). The Benefits of Being Present: Mindfulness and Its Role in Psychological Well-Being. Journal of Personality and Social Psychology, 84(4), 822-848. DOI: 10.1037/0022-3514.84.4.822

Cachia, R. L., Anderson, A. \&Dennis William Moore, D. W. (2016).Mindfulness in Individuals with Autism Spectrum Disorder: A Systematic Review and Narrative Analysis. Review Journal of Autism and Developmental Disorders, 3(2), 123. DOI: 10.1007/s40489-016-0074-0

Chiesa, A., \&Serretti, A. (2009). Mindfulness-based stress reduction for stress management in healthy people: a review and meta-analysis. The Journal of Alternative and Complementary Medicine, 15, 593-600.

Coman, D.; Alessandri, M; Guitierrez, A.; Novotny, S.; Boyd, B. A.; Hume, K. \& Odom, S. (2012). Commitment to classroom model philosophy and burnout symptoms among high fidelity teachers implementing preschool programs for children with autism spectrum disorders.Journal of Autism \& Developmental Disorders, 43(2):345-360.

Craig, C. J. (2017). International teacher attrition: Multi-perspective views. Teachers and Teaching: Theory and Practice,23, 859-862.https://doi. org/10.1080/13540602.2017.1360860

Cunningham, W. G. (1983). Teacher burnoutsolutions for the 1980s: A review of the literature. Urban Review, 15, 37-51.

Demerouti, E., \& Bakker, A. B. (2008). The Oldenburg Burnout Inventory: A good alternative to measure burnout and engagement. In $\mathbf{J}$. Halbesleben (Ed.), Handbook of stress and burnout in health care (pp. 65-78). Hauppauge, NY: Nova Science Publishers.

Demerouti, E., \&Nachreiner, F. (1998).ZurSpezifität von Burnout fürDienstleis- tungsberufe: FaktoderArtefakt [The specificity of burnout for human services: Fact or artefact]. ZeitschriftfürArbeitswissenschaft, 52, 82-89.

Demerouti, E., Bakker, A. B., Nachreiner, F., \&Schaufeli, W. B. (2001). The job demandsresources model of burnout. Journal of Applied Psychology, 86(3), 499-512. http://dx.doi.org/10.1037/0021-9010.86.3.499

Demerouti, E., Bakker, A. B., Nachreiner, F., \&Schaufeli, W. B. (2001). The job demandsresources model of burnout. Journal of Applied Psychology, 86(3), 499512. https://doi.org/10.1037/0021-9010.86.3.499 
Demerouti, E., Mostert, K., \& Bakker, A. B. (2010). Burnout and work engagement: A thorough investigation of the independency of both constructs. Journal of Occupational Health Psychology, 15(3), 209-222. http://dx.doi.org/10.1037/a0019408

Droogenbroeck, F., Spruyt, B. \&Vanroelen, Ch. (2014). Burnout among senior teachers: Investigating the role of workload and interpersonal relationships at work. Teaching and Teacher Education, 43.https://doi.org/10.1016/j.tate.2014.07.005.

Emery, D. W. \& Vandenberg, B. (2010).Special education teacher burnout and ACT. International Journal of Special Education, 25, 119-131.

Epstein-Lubow, G., McBee, L., Darling, E., Armey, M., \& Miller,I. W. (2011).A pilot investigation of mindfulness-based stressreduction for caregivers of frail elderly.Mindfulness, 2(2),95-102.

Extremera, N., Durán, A., \& Rey, L. (2010).Recursospersonales, síndrome de estarquemadopor el trabajo y sintomatologíaasociada al estrés en docentes de enseñanzaprimaria y secundaria [Personal resources, burnout syndrome and symptomology associated with stress in primary and secondary teachers]. Ansiedad y Estrés, 16(1), 47-60.

Figueiredo-Ferraz, H., Grau-Alberola, E., \& GilMonte, P. (2016).Influencia de los valores y la culpa en el síndrome de burnout.Psicologia do Trabalho e das Organizações. 85-95. Recuperado de

https://www.uv.es/unipsico/pdf/Publicaciones/Ca pitulos/01_SQT/2016_Braga.pdf

Fjorback L. O., Arendt, M., Ørnbøl, E., Fink, P., \&Walach, H. (2011). Mindfulness-Based Stress Reduction and Mindfulness-Based Cognitive Therapy - a systematic review of randomized controlled trials. The ActaPsychiatricaScandinavica, 124, 102-119.

Ford, T. G., Olsen, J., Khojasteh, J., Ware, J., \&Urick, A. (2019). The effects of leader support for teacher psychological needs on teacher burnout, commitment, and intent to leave. Journal of Educational Administration, 57(6), 615-634. DOI 10.1108/JEA-09-2018-0185

Fore, C., III, Martin, C., \& Bender, W. N. (2002). Teacher burnout in special education: The causes and the recommended solutions.High School Journal, $\quad 86, \quad 36-44$. https://doi.org/10.1353/hsj.2002.0017
Gil-Monte, P. (2007). El síndrome de quemarsepor el trabajo (burnout) unaperspectivahistórica.En GilMonte PR, Moreno-Jiménez B, editores. El síndrome de quemarsepor el trabajo (burnout)(1 era ed.) Madrid: Pirámide, p. 21-42.

Gray, K., Keating, C., Taffe, J., \& Brereton, A. (2012).Trajectory of behavior and emotional problems in autism.American Journal on Intellectual and Developmental Disabilities, 117, 121-133.

Guskey, T.R., \&Passaro, P.D. (1994). Teacher efficacy: A study of construct dimension. American Educational Research Journal, 31, 627643.

Guskey, T.R., \&Passaro, P.D. (1994). Teacher efficacy: A study of construct dimension. American Educational Research Journal, 31, 627643.

Harmony, C., Woodard, C.R. Mindfulness Training for Staff in a School for Children with Autism and Other Developmental Disabilities: Effects on Staff Mindfulness and Student Behavior.Advances in Neurodevelopmental Disorders,4, 113121.https://doi.org/10.1007/s41252-020-00148-9

Hartley, S. L., Sikora, D. M., \& McCoy, R. (2008).Prevalence and risk factors of maladaptive behavior in young children with autistic disorder.Journal of Intellectual Disability Research, 52, 819-829.

Hastings, R. P., Horne, S. \&Mitchell G. (2004). Burnout indirect care staff in intellectual disabilityservices: a factor analytic study the Maslachburnout inventory.Journal of Intellectual Disabilities Research, 48, 268-273.

Hofmann, S. G., Sawyer, A. T.,Witt, A. A., \& Oh, D. (2010). The effectof mindfulness-based therapy on anxiety and depression: a metanalyticreview. Journal of Consulting and Clinical Psychology,78, 169.

Hole, Y., \&Snehal, P. \&Bhaskar, M. (2018).Service marketing and quality strategies. Periodicals of engineering and natural sciences,6 (1), 182-196.

Hole, Y., \&Snehal, P. \&Bhaskar, M. (2019). Porter's five forces model: gives you a competitive advantage. Journal of Advanced Research in Dynamical and Control System, 11 (4), 14361448.

Huberman, M. (1993).Burnout in teaching careers.European Education, 25, 47-69. 
Jacobson, D. A. (2016). Causes and Effects of Teacher Burnout.PhD Thesis, College of Education, Walden University.

Jennett, H. K., Harris, S. L., Mesibov, G. B. (2003). Commitment to philosophy, teacher efficacy, and burnout among teachers of children with autism.Journal of Autism and Developmental Disorders, 33, 583-593.

Jennett, H. K.; Harris, S. L. \&Mesibov, G. B. (2003).Commitment to philosophy, teacher efficacy, and burnout among teachers of children with autism. Journal of Autism Developmental Disorders,33,583-593.

Johnson, S., Cooper, C., Cartwrights, S., Donald, I., Taylor, P., \& Millet, C. (2005).The experience of work-related stress across occupations.Journal of Managerial Psychology, 20, 178-187. doi:10.1108/02683940510579803.

Kabat-Zinn, J. (2003). Mindfulness-based interventions in context:Past, present, and future. Clinical Psychology: Science and Practice,10(2), 144-156.

Kallapiran, K.; Koo, S., Kirubakaran, R. \& Hancock, K. (2015). Effectiveness of mindfulness in improving mental health symptoms of children and adolescents: a meta-analysis. Child and Adolescent Mental Health, 20(4), 1-20. DOI:10.1111/camh.12113

Kanne, S. M., \&Mazurek, M. O. (2011). Aggression in children and adolescents with ASD: Prevalence and risk factors. Journal of Autism and Developmental Disorders, 41, 926-937.

Keenan-Mount, R., Albrecht, N. J., \& Waters, L. (2016). Mindfulness-based approaches for Young People with Autism Spectrum Disorder and their Caregivers: Do these Approaches Hold Benefits for Teachers? Australian Journal of Teacher Education, 41(6). Retrieved fromhttp://ro.ecu.edu.au/ajte/vol41/iss6/5

Khoury, B., Lecomte, T., Fortin, G., Masse, M., Therien, P., Bouchard, V., et al. (2013). Mindfulness-based therapy: A comprehensivemeta-analysis. Clinical Psychology Review, 33(6), 763-771.

Klassen, R. M., Chiu, M. M. (2010). Effects on teachers' self-efficacy and job satisfaction: Teacher gender, yearsof experience, and job stress. Journal of Educational Psychology, 102, 741-756.

Kohls, N., Saver, S., Walach, H. (2009).Facets of mindfulness.Anonline study investigating the
Freiburg MindfulnessInventory.Personality Individual Differences, 46, 224-230.

Krogmann, R. (2019). School-based mindfulness intervention for adolescents with Autism Spectrum Disorder.Educational Specialist, 149.https://commons.lib.jmu.edu/edspec201019/1 49

Kyriacou, C. (1987). Teacher stress and burnout: An international review. Educational Research, 29, 146-152.

Kyriacou, C. (2001). Teacher stress: Directions for future research. Educational Review, 53, 27-35. https://doi.org/10.1080/00131910120033628.

Kyriacou, C., \& Sutcliffe, J. (1977). Teacher stress: A review. Educational Review, 29, 299-306.

Lee, Y. L., Patterson, P. P., \& Vega, L. A. (2011).Perils to self-efficacyperceptions and teacher-preparation quality amongspecial education intern teachers.Teacher Education Quarterly,38, 61-76.

Leko, M. M., \& Smith, S. W. (2010). Retaining beginning special educators: What should administrators know and do? Intervention in School and Clinic, 45, 321-325. https://doi.org/10.1/1053451209353441

Li, Ch.; Kiu, N.; Raymond, K.W., Yu, Ch. W. (2019).Preservice Teachers' Mindfulness and Attitudes Toward Students with Autism Spectrum Disorder: The Role of Basic Psychological Needs Satisfaction. Adapted Physical Activity Quarterly, 2019, 36, 150-163 https://doi.org/10.1123/apaq.2018-0044.

Lunsky, Y.; Hastings, R. P.; Weiss, J. A.; Palucka, A. M.; Hutton, S. \&White, K. (2017). Comparative Effects of Mindfulness and Support and Information Group Interventions for Parents of Adults with Autism Spectrum Disorder and Other Developmental

Disabilities.The Journal of Autism and Developme ntal Disorders, 47(12), 1-11.DOI 10.1007/s10803-017-3099-z

Martínez-Monteagudo, M. C.; Inglés, C. J.; Granados, L., Aparisia, D. \&García-Fernándeza, J. M. (2019). Trait emotional intelligence profiles, burnout, anxiety, depression, and stress in secondary education teachers. Personality and Individual Differences, 142(1), 53-61.

Maslach, C. (1976) Burn-Out.Human Behavior, 5, 16-22. 
Maslach, C. and Jackson, S.E. (1986). Maslach burnout inventory. $2^{\text {nd }}$ Edition, Consulting Psychologists Press, Palo Alto.

Maslach, C.; Jackson, S. E. \&Leiter, M. (1996). Maslach burnout inventory manual. 3rd ed. Palo Alto: Consulting Psychologists Press.

Maslach, J. \& Jackson, S. E. (1981).The measurement of experienced burnout. Journal of Occupational Behavior, 2, 99-113.

Mazurek, M. O., \&Kanne, S. M. (2010).Friendship and internalizing symptoms among children and adolescents with ASD.Journal of Autism and Developmental Disorders, 40, 1512-1520.

Nistor, A. A., \& Chilin, T.-F. (2013). Challenging behavior of children with intellectual disabilities and its relation to burnout for those working with them: A systematic review. The Scientific Journal of Humanistic Studies, 5(9), 119.

Pajares F, Johnson MJ, Usher EL. Sources of writing self-efficacy beliefs of elementary, middle, andhigh school students. Research in the Teaching of English, 42,104-120.

Piet, J., Würtzen, H., \&Zachariae, R. (2012). The effect of mindfulness-based therapy on symptoms of anxiety and depressionin adult cancer patients and survivors: A systematic review and metaanalysis. Journal of Consulting and Clinical Psychology,80(6), 1007.

Rabasa, B., Figueiredo-Ferraz, H., Gil-Monte, P., \&Llorca-Pellicer, M. (2016).El papel de la culpa en la relación entre el síndrome de quemarsepor el trabajo y la inclinación al absentismo de profesores de EnseñanzaSecundaria.Revista de Psicodidáctica, $\quad$ 2l(1), 103-119. http://www.ehu.eus/ojs/index.php/psicodidactica/a rticle/viewFile/13076/13429.

Rattaz, C., Ledesert, B., Masson, O., Ouss, L., Ropers, G., \&Baghdadli, A. (2013a). Etat des lieux des pratiquesd'accompagnement sanitaire etmédico-sociale des personnes avec Troubles Envahissants du Développement (TED) danstroisrégionsfrançaises. Neuropsychiatrie de l'enfanceet de l'adolescence, 61, 31-38. doi:10.1016/i.neurenf.2012.10.001.

Ridderinkhof, A., de Bruin, E. I., Blom, R., \&Bögels, S. M. (2018). Mindfulness-Based Program for Children with Autism Spectrum Disorder and Their Parents: Direct and Long-Term Improvements. Mindfulness, 9(3), 773-791. https://doi.org/10.1007/s12671-017-0815-X
Ruble, L.A., Usher, E.L., \& McGrew, J.H. (2011). Preliminary investigation of the sources of selfefficacy among teachers of students with autism.Focus on Autism and Other Developmental Disabilities, 26(2), 67-74.

Ruble, L.A., Usher, E.L., \& McGrew, J.H. (2011). Preliminary investigation of the sources of selfefficacy among teachers of students with autism.Focus on Autism and Other Developmental Disabilities, 26(2), 67-74.

Salo, K. (1995). Teacher stress and coping over an autumn term in Finland. Work \& Stress, 9, 55-66.

Schell, L. K., Monsef, I., Wöckel, A., \&Skoetz, N. (2019). Mindfulness-based stress reduction for women diagnosed with breast cancer. The Cochrane database of systematic reviews, 3(3), CD011518.https://doi.org/10.1002/14651858.CD0 11518.pub2

Schwarzer R, Hallum S. Perceived teacher selfefficacy as a predictor of job stress and burnout: Mediation analyses. Applied Psychology: An International Review.2008; 57:152-171.

Schwarzer, R., \& Jerusalem, M. (1995).Generalized self-efficacy scale. In J. Wein- man, S. Wright, \& M. Johnston (Eds.), Measures in health psychology: A user's portfolio (pp. 35-38). Windsor: NFER-Nelson.

Schwarzer, R., Schmitz, G.S., \&Daytner, G.T. (1999).The Teacher Self-Efficacy scale [On-line publication]. Available at: http://www.fuberlin.de/gesund/skalen/ t_se.htm

Segal, Z. V., Williams, J. M. G., \& Teasdale, J. D. (2012).Mindfulness-based cognitive therapy for depression. New York: Guilford Press.

Segal, Z. V., Williams, J. M. G., Teasdale, J. D. (2007). Mindfulness-Based Cognitive Therapy for Depression: A New Approach to Preventing Relapse. Cognitive Behavioral Therapy Book Reviews, $3(11)$, http://www.CognitiveTherapyAssociation.org/cbt br.aspx

Seidman, S., \&Zager, J. (1991).A study of coping behaviors and teacher burnout.Work \& Stress, 5, 205-216.

Sequeira, S., \& Ahmed, M. (2012). Meditation as a potential therapy for autism: a review. Autism Research Treatment.https://doi.org/10.1155/2012/835847.

Singh, N. N.; Lancioni, G. E.; Winton, A. S. W.; Karazsia, B.; Myers, R. E.; Latham, L. L.; \& 
Singh, J. (2014). Mindfulness-Based Positive Behavior Support (MBPBS) for Mothers of Adolescents with Autism Spectrum Disorder: Effects on Adolescents' Behavior and Parental Stress. Mindfulness, 5(6), 646657.Doi:10.1007/s12671-014-0321-3.

Spain, D., Harwood, L. and O'Neill, L. (2015).Psychological interventions for adults with autism spectrum disorders: A review. Advances in Autism,1(2), 7986. https://doi.org/10.1108/AIA-05-2015-0007

Tschannen-Moran, M., Woolfolk Hoy, A., \& Hoy, W.K. (1998). Teacher efficacy: Its meaning and measure. Review of Educational Research, 68, 202248. doi:10.3102/00346543068002202

Tschannen-Moran, M., Woolfolk Hoy, A., \& Hoy, W.K. (1998). Teacher efficacy: Its meaning and measure. Review of Educational Research, 68, 202-248. doi:10.3102/00346543068002202

Van der Oord, S., Bögels, S. M., \&Peijnenburg, D. (2012).The effectivenessof mindfulness training for children with ADHD andmindful parenting for their parents.Journal of Child and FamilyStudies, 21(1), 139-147.
Wallace, B. A., Shapiro, S. L. (2006). Mental balance and well-being:building bridges between Buddhism and Western psychology.American Psychologist,61, 690-701.

Weiss H. M. (2002). Deconstructing job satisfaction:Separating evaluations, beliefs, and affectiveexperiences. Human Resource Management Review, 12,173-194.

Whitebird, R. R., Kreitzer, M., Crain, A. L., Lewis, B. A., Hanson, L. R., \&Enstad, C. J. (2012). Mindfulness-based stress reduction for family caregivers: a randomized controlled trial. The Gerontologist,53(4), 676-686.

Wilcoxon, F. (1945). Some Rapid Approximate Statistical Procedures.American Cyanamid Co. Stamford Research Laboratories.

Zarafshan, H., Mohammadi, M. R., Ahmadi, F., \&Arsalani, A. (2013). Job burnout among Iranian elementary school teachers of students with Autism: A comparative study. Iranian journal of psychiatry, 8(1), 20-27. 